which three structurally similar genes ( $m n p 1, m n p 2$, and mnp3) and two other newly isolated genes were achieved from $P$. chrysosporium [16]. White-rot fungi secrete $\mathrm{MnP}$ mainly in multiple types. They are numerous glycoproteins with a molecular weight ranging from 38 to $62.5 \mathrm{kDa}, \sim 350$ amino acid residues, and have $43 \%$ of identity with LiP sequences [17].

The two domains with heminic group in center, one minor helix, ten major helixes, and five disulfide bridges have been responsible for the formation of MnP enzymes. Out of these, one takes part in manganese bonding site. This site is attributed to differentiate $\mathrm{MnP}$ from other reported peroxidases [18]. The improved MnP production is important for assisting to create environmentally sound biomass degradation alternatives and diminish the cost of energy and used chemicals in biofuel production industries. MnP has many applications in industrial processes like bio-pulping, bio-bleaching and biodegradation/bioremediation of pollutants [3, 4, 19-21].

The catalytic cycle of $\mathrm{MnP}$ is commencement by indigenous ferric enzyme and $\mathrm{H}_{2} \mathrm{O}_{2}$ to form compound I, which is a $\mathrm{Fe}^{4+}$ oxo-porphyrin radical complex, while mono-chelated $\mathrm{Mn}^{2+}$ ions give $1 \mathrm{e}^{-}$to porphyrin intermediated to compound II by the donation of $1 \mathrm{e}^{-}$form $\mathrm{Mn}^{2+}$ to form $\mathrm{Mn}^{3+}$. Further, chelated $\mathrm{Mn}^{3+}$ ions generated by $\mathrm{MnP}$ act as $\mathrm{S}-\mathrm{S}$ charge transfer mediators, allowing the oxidation of various phenolic substrates like simple phenols, amines, phenolic lignin and several dyes (Fig. 1) [10, 21].

$\mathrm{MnP}$ has potential biotechnological as well as several bioremediation applications such as production of natural aromatic flavor, decoloration of various industrial wastewaters such as textile, distillery, pulp and paper, and many other wastewaters [2, 4, 22]. So far, many findings are available on MnP applications, but these are scattered; hence,
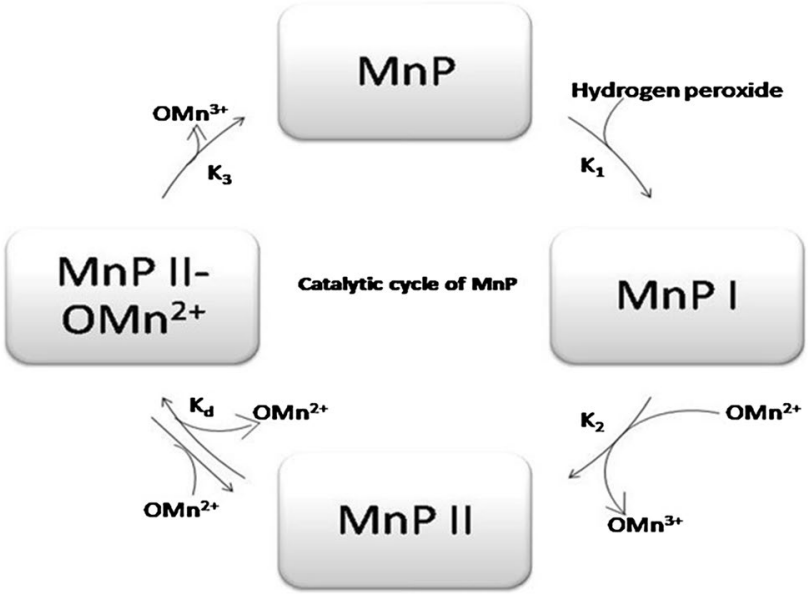

Fig. 1 Catalytic cycle of Manganese peroxidase enzyme this review is to compile all important information at a single place.

\section{Source of $\mathrm{MnP}$}

Many researchers have observed that MnPs are found in many microorganisms such as bacteria, fungi, and algae. $[23,24]$. A fungus produces/secretes one or more of three extracellular enzymes that are necessary for lignin degradation: LiP, MnP, and laccase. An extracellular MnP produced by P. sordida, P. chrysosporium, P. radiata, P. rivulosu, C. subvermispora, and Dichomeris squalens, [25]. MnP produced by P. chrysosporium BKM-1767 was observed during the growth in several medium and environmental as well as nutritional growth conditions [26]. On the other hand, there is an urgent need to find $\mathrm{MnP}$ with higher tolerance to organic solvent and inorganic ions to enhance the degradation potential of xenobiotics. In this context, Qin et al. [27] found that some substrate/mediators such as veratryl alcohol, oxalic acid, 2, 6-Dimethoxyphenol could catalyze the synthesis of $\mathrm{MnP}$ in Irpex lacteus CD2. In addition, earlier potential strain was characterized as $A$. baumanii based on phylogenetic tree of 16 rRNA sequencing. Above findings have given a number of important microbial strains capable for delignification and biodegradation of recalcitrant compounds by ligninolytic enzymes [28].

Huy et al. [29] found that the wood chips or rice straw can be used as chief carbon source and recognized as inexpensive medium of agricultural residue for the production of $\mathrm{MnP}$ from Fusarium sp. Further, $\mathrm{MnP}$ with molecular mass of $45 \mathrm{kDa}$ was purified from the white-rot fungus C. unicolor BBP6 and named as MnP-BBP6 with optimum temperature and $\mathrm{pH}$ [24]. Now these days, the degradation of lignin and rice straw has great attention especially in Egypt and worldwide due to the accumulation of rice straw as agricultural wastes that cause many environmental problems worldwide.

A. praecox produces extracellular $\mathrm{MnP}$, which mineralizes synthetic lignin. The isolated MnP1 isozyme of $A$. praecox was also characterized, purified, and cloned. Hence, this newly isolated MnP1 may represent a novel group of a typical short-MnP enzyme [30]. MnP production is predominantly found in Bjerkandera adusta, F. fomentarius, Cerrena and Trametes genera. Earlier, it was also found that $\mathrm{MnP}$ production in $P$. chrysosporium is enhanced by nutrient limitation such as $\mathrm{C}, \mathrm{N}$, and also by $\mathrm{Mn}^{2+}$. By contrast, mnp3 lacks MREs, and it was observed that transcript levels are not disturbed by the addition of $\mathrm{Mn}^{2+}[31,32]$. Cupriavidus basilensis B-8 produces both ligninolytic enzyme laccase and MnP during the lignin biodegradation [33]. Irpex lacteus has a great prospective in bio-pretreatment of lignocellulose as well as in biodegradation of xenobiotics. 
I. lacteus showed to produce $\mathrm{MnP}$ as the main enzyme under many controlled tested conditions $[27,34]$.

\section{Physicochemical and molecular properties of $\mathrm{MnP}$}

Ligninolytic enzymes production and activities are affected by many environmental and nutritional parameters such as $\mathrm{pH}$, temperature, carbon, and nitrogen (Table 1). Size exclusion and anion exchange chromatography were used as conventional method for the purification of MnP enzyme. The SDS-PAGE analysis revealed that the purified $\mathrm{MnP}$ is a monomeric protein having mol. wt. of $37 \mathrm{kDa}$ with an isoelectric point at 3.55. The optimum $\mathrm{pH}$ ranges from 4.0 to 7.0 with a peak at $\mathrm{pH}$ 5.5. It was also found that $\mathrm{MnP}$ was more active at $5-70^{\circ} \mathrm{C}$ with an optimum between 50 and $60^{\circ} \mathrm{C}$. At temperatures above $65^{\circ} \mathrm{C}$, the enzyme quickly vanished activity [46]. In native protein, the heme-iron has high-spin, pentacoordinate form, and ferric state with a His-residue coordinate at the fifth ligands position [49]. MnP has 5 rather than four $\mathrm{S}-\mathrm{S}$ bond, with the additional bond, Cys341-Cys348, located near the $\mathrm{C}$ terminus of the polypeptide chain. The extra S-S bond assists to form $\mathrm{Mn}$ (II) binding site, and it is responsible for driving the $\mathrm{C}$ terminus part away from the foremost part of protein $[50,51]$.

Oxidoreductase can catalyze oxidation of an extensive variability of organic compounds using hydrogen peroxide. It is an environmentally low load oxidant and has been used in industry for several purposes such as food processing and oil bio-refining, while in industries the fullscale use of peroxidases is still restricted due to their facile inactivation in the presence of $\mathrm{H}_{2} \mathrm{O}_{2}$ under supra-physiological conditions. Moreover, peroxidases poor thermal and environmental tolerance reduces the range of practical uses [52]. The reaction of catalytic cycle is initiated with the transfer of $2 \mathrm{e}^{-}$from heminic group to $\mathrm{H}_{2} \mathrm{O}_{2}$, and finally, it form compound I and water. Further, compound I catalyzes the oxidation of one substrate compounds with the formation of free radicals and compound II. However, compound II oxidizes $\mathrm{Mn}^{2+}$ to form $\mathrm{Mn}^{3+}$, and the cation is responsible to oxidize aromatic ring containing compounds. It is necessary to know that compound II demands $\mathrm{Mn}^{2+}$ presence for its reaction, whereas compound I can oxidize $\mathrm{Mn}^{2+}$ or the substrate molecules. Subsequently, $\mathrm{Mn}^{3+}$ became stabilized by organic acids; it reacts nonspecifically with organic compounds by eliminating 1 $\mathrm{e}^{-}$and proton from the substrate molecules [17]. MnP is relatively precise for reducing substrates, and only $\mathrm{Mn}^{2+}$ efficiently supports enzyme turnover. Direct oxidation of $\mathrm{Mn}$ (II) to $\mathrm{Mn}$ (III) is characteristic of MnP, although other enzymes can oxidize it via superoxide anion radical. The chelators affect the interaction of $\mathrm{Mn}$ ions at the active site of enzyme as shown by kinetic studies [53]. Although the $\mathrm{MnP} / \mathrm{Mn}^{2+}$ pair is not oxidized non-phenolic lignin model dimers as LiP does, partial depolymerisation of synthetic as well as plant derived lignin has been formed possibly by endwise attack progressing from phenolic components [54]. The enzyme production and activity were determined by following points discussed as below:

- The enzyme yield varies species to species and strain to strain, and assortment of newly isolated microorganisms with large production of these enzymes is possible.

- During the enzyme production process, lignocellulosic materials and $C$ source play an important role.

- The activity of ligninolytic enzymes not only regulated by the aromatic compounds, but it also depends upon the physiological activity of microorganisms.

- Selection and co-cultivation of suitable fungus shows substantial promise as an approach to accelerate/promote the enzyme production [55].

However, after the above-mentioned selection procedure, optimization plays a key role in enzyme production with the selected microorganism. Several studies clearly specified that basidiomycetes showed a wide variety in their response to $C$ sources and their optimum concentration in selected medium $[56,57]$. In $P$. robustus kiwi residue stimulates the $\mathrm{MnP}$ secretion in compression with wheat barn. Consequently, after the substitution of wheat bran by pericarp laccase/MnP ratio changes from 226 to 2 [55]. In some fungal species like $P$. chrysosporium, the ligninolytic enzyme gene expression is activated only by the diminution of $C$ sources [57]. There are various compounds, like dimethoxyphenol (2,6-DMP), which affects the ligninolytic enzyme activity, and production to the control medium increased the MnP yields twofold. In addition, vanillic acid followed by the ferulic acid and veratric acid and pyrogallol enhances $\mathrm{MnP}$ activity more than $50 \%$ in C. unicolor [55].

\section{Effects of various parameters on enzyme activity}

Nutritional as well as environmental factors affect the production and activity of ligninolytic enzymes including $\mathrm{MnP}$ in various ways (Table 2). The optimum $\mathrm{pH}$ and temperature range from organism to organism. Ligninolytic enzyme (Lac, LiP, MnP) activity or production not only depends on the microbial species but also depends on culture conditions, carbon, and nitrogen sources and their concentration [61, 70, 71]. Pedri et al. [72] observed that 
Table 1 Various MnP producing microorganisms, growth medium and physiological properties

\begin{tabular}{|c|c|c|c|c|c|c|c|c|}
\hline Microorganism & $\begin{array}{l}\text { Microbes growth } \\
\text { Source }\end{array}$ & $\begin{array}{l}\text { Molecu- } \\
\text { lar mass } \\
(\mathrm{kDa})\end{array}$ & $\begin{array}{l}\text { Used Substrate in } \\
\text { assay }\end{array}$ & $\begin{array}{l}\text { Temp. optima } \\
\text { of activity }\left({ }^{\circ} \mathrm{C}\right)\end{array}$ & $\begin{array}{l}\text { Temp. } \\
\text { stability } \\
\left({ }^{\circ} \mathrm{C}\right)\end{array}$ & $\begin{array}{l}\mathrm{pH} \\
\text { optima of } \\
\text { activity }\end{array}$ & pH stability & References \\
\hline \multicolumn{9}{|l|}{ Fungus } \\
\hline $\begin{array}{l}\text { Cerrena unicolor } \\
\text { BBP6 }\end{array}$ & $\begin{array}{l}\text { Dyes containing } \\
\text { agar plates }\end{array}$ & 45 & Gallic acid & 60 & NR & 4.5 & 4.8 & [24] \\
\hline $\begin{array}{l}\text { Ganoderma } \\
\text { lucidum }\end{array}$ & $\begin{array}{l}\text { Potato dextrose } \\
\text { agar }\end{array}$ & 37.72 & NR & NR & NR & NR & NR & {$[35]$} \\
\hline Trametes sp.48424 & $\begin{array}{l}\text { Potato dextrose } \\
\text { broth (PDB) }\end{array}$ & 49 & Veratric acid & 70 & NR & 5.0 & NR & [36] \\
\hline $\begin{array}{l}\text { Ganoderma luci- } \\
\text { dum IBL-05 }\end{array}$ & Wheat bran & 43 & & 30 & $20-60$ & 4.5 & - & [37] \\
\hline Irpex lacteus F17 & $\begin{array}{l}\text { Solid-state fermen- } \\
\text { tation medium }\end{array}$ & - & - & 40 & - & 3.5 & - & [38] \\
\hline Irpex lacteus CD2 & $\begin{array}{l}\text { Potato dextrose } \\
\text { agar }\end{array}$ & - & Veratryl alcohol & 28 & $40-70$ & 4.5 & 6.0 & [27] \\
\hline Trametes villosa & Sugarcane bagasse & - & - & - & 22 & 7.0 & & [39] \\
\hline Agrocybe praecox & $\begin{array}{l}\text { Bark mulch and } \\
\text { wood chips }\end{array}$ & 42 & - & - & - & 4.5 & 7.0 & [30] \\
\hline $\begin{array}{l}\text { Phanerochaete } \\
\text { chrysosporium }\end{array}$ & Wheat Straw & 52.8 & - & $28-38$ & - & - & - & {$[40]$} \\
\hline $\begin{array}{l}\text { P. chrysosporium; } \\
\text { Fusarium sp.89; } \\
\text { Fusarium sp. } 82\end{array}$ & Rice straw & - & - & - & - & - & - & [41] \\
\hline $\begin{array}{c}\text { Phanerochaete } \\
\text { chrysosporium }\end{array}$ & $\begin{array}{l}\text { Agriculture by- } \\
\text { products }\end{array}$ & - & - & - & - & - & - & [42] \\
\hline P. chrysosporium & $\begin{array}{l}\text { Agro-industrial } \\
\text { wastes }\end{array}$ & - & - & 35 & - & 4.5 & - & [43] \\
\hline $\begin{array}{l}\text { Schizophyllum } \\
\text { commune IBL-06 }\end{array}$ & Banana waste & - & $\mathrm{MnSO}_{4}$ & 35 & - & 4.5 & - & [44] \\
\hline C. subvermispora & $\begin{array}{l}\text { Japanese beech } \\
\text { and cedar wood } \\
\text { Eucalyptus } \\
\text { grandis wood } \\
\text { Bamboo culms }\end{array}$ & - & Phenol red & 30 & - & - & - & {$[45]$} \\
\hline $\begin{array}{r}\text { Irpex lacteus } \\
\text { CCBAS238 }\end{array}$ & MEG agar slant & 37 & - & $50-60$ & 65 & $4-7$ & 5.5 & {$[46]$} \\
\hline Phlebia radiata & Wheat straw & 68 & - & - & - & - & - & [47] \\
\hline \multicolumn{9}{|l|}{ Bacteria } \\
\hline $\begin{array}{c}\text { Acinetobacer } \\
\text { baumanii }\end{array}$ & Rice straw & - & - & - & - & - & - & [28] \\
\hline Bacillus subtilis & Mineral salt media & 68 & $\mathrm{MnSO} 4$ & 30 & - & - & - & [3] \\
\hline $\begin{array}{l}\text { Alcaligenes faeca- } \\
\text { lis (DQ659619) } \\
\text { and Bacil- } \\
\text { lus cereus } \\
\text { (DQ659620) }\end{array}$ & GPYM agar plates & 43 & Phenol red & & - & - & - & [48] \\
\hline
\end{tabular}

$N R$ not reported

maximum concentration of ammonium sulfate and potassium nitrate showed negative effects on enzyme activity, whereas maximum activity was observed in the presence of ammonium sulfate and soyabean. In culture broth, nitrogen source enhances microbial cell growth and also boosts the enzymes expressions [73]. Prasher and Chauhan [74] found that glucose and ammonium oxalate were more effective carbon and nitrogen source, respectively, for the highest manganese peroxidase enzyme activity and production. In recent studies, the maximum activity of ligninolytic enzyme was reported at $24^{\circ} \mathrm{C}$ temperature and $\mathrm{pH}$ from 5 to 9. [74, 75]. In earlier study, it was observed that 
Table 2 Factors affecting MnP enzyme activity and their production

\begin{tabular}{|c|c|c|}
\hline Factors & Comments & $\begin{array}{l}\text { Refer- } \\
\text { ences }\end{array}$ \\
\hline Carbon source & $\begin{array}{l}\text { The maximum LiP activities and noticeable levels of } \mathrm{MnP} \text {, when they used wood as a } \mathrm{C} \text { source with milled } \\
\text { alder as inducer } \\
\text { The maximum activities of MnP were obtained in pineapple peel culture }\end{array}$ & [58] \\
\hline Nitrogen source & $\begin{array}{l}\text { P. chrysosporium cultivated in synthetic medium, producer LiP and } \mathrm{MnP} \text { only under } \mathrm{N} \text { limited condition. } \\
\text { However, it was found that in the presence of ligninolytic substrate, a high } \mathrm{N} \text { concentration stimulates } \\
\text { these enzymes production } \\
\text { Several inorganic and organic } \mathrm{N} \text { sources in submerged fermentation of wheat bran to improve enzyme } \\
\text { production by Ganoderma lucidum. The maximal valve of laccase activity was revealed in supplementation } \\
\text { of culture media with } \mathrm{KNO}_{3} \text {. The compound slightly stimulated } \mathrm{MnP} \text { accumulation }\end{array}$ & $\begin{array}{l}{[59-61]} \\
{[62]}\end{array}$ \\
\hline Synthetic inducer & $\begin{array}{l}\text { MnP activity was induced by Tween- } 80 \text {. Addition of Tween } 80 \text { caused the highest values of MnP activity } \\
\text { produced by P. chrysosporium }\end{array}$ & [63-65] \\
\hline Metal inducers & $\begin{array}{l}\text { Manganese (Mn) plays a regulatory role in the expression of LiP, MnP, Lac and in the degradation of lignin. It } \\
\text { seems that low concentrations of essential heavy metals are necessary for the development of ligninolytic } \\
\text { enzyme system } \\
\text { Addition of low concentration of } \mathrm{Zn} \text { and Cu into the metal free synthetic cultivation medium increased the } \\
\text { activity of LiP and MnP of } P \text {. chrysosporium }\end{array}$ & [66-68] \\
\hline $\mathrm{pH}$ & $\begin{array}{l}\mathrm{MnP} \text { and Lac were activity commonly detected in the less acidic }(\mathrm{pH}>5.0) \text {, whereas no } \mathrm{MnP} \text { activities are } \\
\text { detected in the highly acidic condition. } \mathrm{MnP} \text { and LiP activities are dependent on } \mathrm{pH} \text { and independent in } \\
\text { the forest floor layer }\end{array}$ & [69] \\
\hline Temperature & Temperature is also play an important role during enzyme activity and other related function & [48] \\
\hline
\end{tabular}

Table 3 Various applications of MnP enzyme

\begin{tabular}{|c|c|c|c|}
\hline S. No. & Enzyme & Applications & References \\
\hline 1. & $\mathrm{MnP}$ & Dye decolorization and denim bleaching & {$[24]$} \\
\hline 2. & $\mathrm{MnP}$ & Degradation of hydroquinone, pyrocatechol, resorcinol, benzoquinone & [35] \\
\hline 3. & $\mathrm{MnP}$ & Adequate treatment of industrial lignin and black liquor & [35] \\
\hline 4. & $\mathrm{MnP}$ & Degradation of various types of lignin containing model compound/modification. & {$[77,78]$} \\
\hline 5. & $\mathrm{MnP}$ & Degradation of various types of dyes and polycyclic aromatic hydrocarbons (PAHs) & [36] \\
\hline 6. & MnP, laccase & Degradation of lignin and rice straw & {$[28]$} \\
\hline 7. & MnP, laccase, LiP & Biodegradation of natural rubber & [3] \\
\hline 8. & $\mathrm{MnP}$ & Bio-ethanol production & [79] \\
\hline 9. & $\mathrm{MnP}$ & $\begin{array}{l}\text { Decolorization and degradation of reactive textile dyes, i.e., Reactive Yellow MERL } \\
\text { (7-(4-\{4-Chloro-6-[3-(2-Sulfoxy-Ethanesulfonyl)-Phenylamino]-[1,3,5,]Triazin- } \\
\text { 2-Ylamino\}-2-Ureido-Phenylazo)-Napthalene-1,3,6,Trisulfonic Acid) And Reactive red } \\
\text { ME4BL(5-\{4-Choloro-6-[4-(2-Sulfo-Ehtanesulfonyl)-Phenylamino]- [1, 3, 5] Triazin- } \\
\text { 2-Ylamino\}-3-(1,5-Disulfo-Napthalen-2-Ylazo)-4-Hydroxy-Naphthalena-2,7-Disulfonic } \\
\text { Acid }\end{array}$ & {$[40]$} \\
\hline 10. & $\mathrm{MnP}$ & Effectively degrade a broad range of synthetic dyes & {$[27]$} \\
\hline 11. & MnP, LiP & Used in diagnostic kits & {$[80]$} \\
\hline 12. & $\mathrm{MnP}$ & Degradation of PAHs degradation of PAHs. & {$[46]$} \\
\hline
\end{tabular}

recombinant $\mathrm{MnP}(\mathrm{rMnP})$ showed optimum production at $\mathrm{pH} 6$ and temperature $30^{\circ} \mathrm{C}$ in P. pastoris [76].

\section{Ample applications/opportunities in various sectors}

In current scenario, ligninolytic enzymes gain more attention in various types of biotechnological application such as in alcohol, pulp and paper, textile, food, medicals and in cosmetic industry and also for biodegradation of many toxic compounds (Table 3 ) $[55,82,83]$. In recent years, ligninolytic enzymes have appeared as a new substitute and ample opportunities in various sector, including research detailed discussed in this section (Fig. 2). 


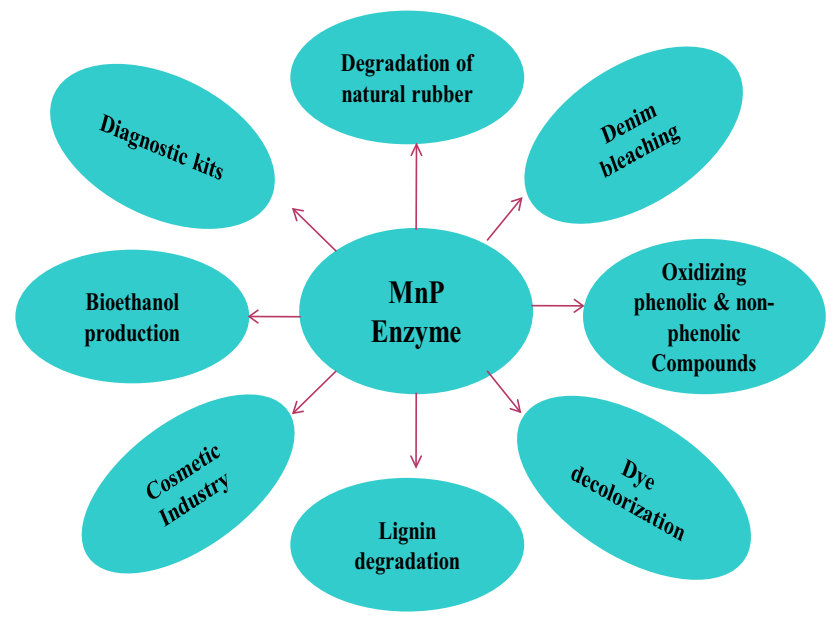

Fig. 2 Manganese peroxidase used in various biotechnological application

\subsection{Degradation of phenolic and non-phenolic compounds}

Phenolic and non-phenolics compounds are found in different industrial wastewaters, including coal conversion, petroleum refining, resins, plastics, wood preservation, metal coal, dyes and other chemicals, textiles, mining and dressing, and pulp and paper. Most applications have focused on the treatment of phenolic contaminants in the presence of $\mathrm{H}_{2} \mathrm{O}_{2}[5,84,85]$. MnP-generated $\mathrm{Mn}$ (III) chelator can induce the oxidation of phenolic compounds, including phenols, amines, dyes, and also dimers and lignin-containing phenolic structure.

Various researchers found that under physiological conditions $\mathrm{Mn}$ (III), chelator acts as mild oxidant and limited to the oxidation of lignin-containing phenolic structures [86, 87]. The $\mathrm{Mn}$ (III) formed is separated from the enzyme and stabilized by forming complexes with a-hydroxy acids at a high redox potential of $0.8-0.9 \mathrm{~V}$. There are two optimal chelators, i.e., malonate and oxalate that are produced in significant amount by fungal species [53]. The oxidation by $\mathrm{Mn}$ (III) engages the development of reactive radicals for non-phenolic substrate in presence of second mediator [88]. In contrast, LiP catalyzed reaction, which involves e- reduction from the aromatic ring forming a radical cation. In the presence of thiols (R-S-H) such as glutathione, $\mathrm{Mn}$ (III) mediates the oxidation of substituted benzyl alcohols and diaryl propane structures into their respective aldehydes [8]. Zhang et al. [36] found that MnP-Tra-48424, which obtained from Trametes sp., has the ability to decolorize divers group of dyes such as indigo, anthraquinone, triphenylmethane and azo dyes.

\subsection{Pulp and paper industry}

Pulp and paper industry is a key contributor in world's economy, but unfortunately it causes various environmental toxicity and health problems. During the paper manufacturing process pulp and paper industry uses huge amount of lignocellulosic materials. Paper manufacturing process involves three main steps like (1) pulping, (2) bleaching and (3) paper production, further pulping divided into three type, i.e., mechanical, chemical and chemi-mechanical or combination pulping (for details see [89]). These processes generate high strength of wastewater, which causes adverse impact on environment. There are several chemical-based treatment technologies available, but are hazardous to living beings, costly and unsafe of green environment, while biological approaches are reported as cost-effective, commercially and environmentally safe approaches for wastewater treatment [90]. For the adequate treatment of discharged wastewater and pollutants, diverse group of microorganism are playing an essential role. Among these, white-rot fungi are found more effective for the degradation of many lignin and other similar wood materials to $\mathrm{CO}_{2}$ and $\mathrm{H}_{2} \mathrm{O}$ [91]. Some of them are potent degrader of lignin rather than cellulose and hemicellulose [92].

A variety of lignocellulosic materials or resources are available for conversion of many value-added bio-products, which increase the research interest in this area [89]. There are problems with the direct use of microbes for degrading lignocellulosic materials, including breaking of cellulosic fibers [93] and long reaction times, extending to long time [94]. Hatakka et al. [95] found that Tween $80, \mathrm{H}_{2} \mathrm{O}_{2}$ generating system, and an organic acid assist the chelation of $\mathrm{MnP}$, in the presence of $\mathrm{Mn}$ (II). However, $\mathrm{Mn}$ (II) is an strong oxidizing agent and an important factor in the delignification system [96]. In pulp and paper industry, enzyme pulping is used for $\mathrm{MnP}$ and laccases of Polyporus sp., and pectinases from Rhizopus sp. $26 \mathrm{R}$ in practice. The application of ligninolytic enzymes reduces the amount of chemicals used in basic pulping process such as sodium hydroxide $(\mathrm{NaOH})$ [97]. However, $\mathrm{MnP}$ and LiP are reported to play an important role in decolorizing of kraft pulp [98, 99].

\subsection{Food industry}

Food quality is not a function of nutritional values, but also of the presence of bioactive compounds, which apply positive effects on human and animal health. Microbial ligninolytic enzyme displays great perspective for variety of industrial application like pulp delignification, wastewater treatment, biofuel production, dye decolorization, biosensors, and juice extraction clarification $[4,100]$. Bilal 
et al. [100] immobilized MnP gives praiseworthy result in which reduction in apple juice color and turbidity was $42.7 \%$ and 36.3 , respectively. In simultaneous study, it was observed that reduction in color and turbidity $51.5 \%$ and $43.6 \%$, respectively. Further, Bilal et al. [101] found that treatment by immobilized ligninolytic enzyme reduces turbidities up to $84.02 \%, 57.84,86.14 \%$ and $82.13 \%$ which was observed for apple, grape, orange and pomegranate juice, respectively. In recent years, MnP have also gained more demands in various applications in food industry. It has great possibility to generate natural aromatic flavors such as vanillin production, ferulic, $\mathrm{p}$-coumaric, syringic and $p$-hydroxybenzoic $[22,102,103]$. This type of research finding is very imperative because recently special attention in biotechnology has been given to acquire massive quantity of low-cost environment friendly ligninolytic enzymes by use of diverse agriculture and food industry residue; unfortunately, it can call serious environmental problems. The residues present excellent substrate for fungal growth, which are mineralized to low molecular weight (LMW) compounds by various lignocellulolytic enzymes including $\mathrm{MnP}$ and other peroxidases. These LMW products are simply absorbed by fungi, better digested by animals, and could be used in the production of high nutritional value food, feeds, and other basic commodities for various industrial uses.

\subsection{Alcohol industries}

Ligninolytic enzymes play an important role in distillery waste treatment process [23, 82]. Enzymatic degradation/ detoxification has been applied in the mitigation of toxicity after different pre-treatments such as steam explosion, strong acids, organosolv, and hot liquid water. In addition, ligninolytic enzyme enhances detoxification, fermentation rates and ethanol production processes in alcohol industry [104]. The enzymatic degradation or decolorization generates an ethanol yields five times more in comparison with ion exchange degradation in sugarcane bagasse [105]. The enzyme has capability to catalyze non-activated alcohols, which is an imperative factor for future degradation or detoxification procedures [106]. For $\mathrm{MnP}$, maximum production was in Aspergillus niger TERI DB20 grown on corncob with wastewater. Pant and Adholeya [107] found that Pleurotus ostreatus (Florida) Eger EM 1303 achieved color reduction $86.33 \%$ of molasses (cane)-based wastewater of distillery industry. Biotechnology treatment encompasses a variety of scientific and engineering treatment methods for applying eco-friendly or biological systems to produce important materials or elimination of problematic, often poisonous, liquid, solid or gaseous wastes.

\subsection{Use of lignocellulosic materials and MnP in bio-ethanol production}

In recent years, concerning renewable biofuel production and bio-ethanol from lignocellulosic feedstocks is considered the most practicable choice for fossil fuels replacement, since these raw materials do not compete with food or feed crops [108]. Treatment by ligninolytic enzyme of waste biomass could be of precise interest, because it seems to be an environmental friendly method for making bio-ethanol. In future, biorefineries will integrate biomass conversion process to produce fuels, power, heat and value-added chemicals. Due to its low price and wide distribution, lignocellulosic biomass is expected to play an important role toward this goal $[20,109]$. To increasing the range of various natural resources scientists have been redirecting their curiosity in biomass-based bio-fuels production, which can be attained from lignocellulosic biomass. They also found that high-performance liquid chromatography (HPLC) analysis is used as promising tool for bio-ethanol production in consecutive saccharification and fermentation [20]. Further, Asgher et al. [2] produced $22.6 \mathrm{~g} / \mathrm{L}$ ethanol by using Saccharomyces cerevisiae with the help of Sequential Saccharification and Fermentation (SSF) process. In recent study, Bilal et al. [110] found that by using extract of ligninolytic enzyme from $G$. lucidum IBL-05 for delignification of newspaper waste followed by saccharification with celluloses extract from Trichoderma harzianum and bio-ethanol production by S. cerevisiae.

\subsection{Miscellaneous and emerging applications}

Agostini et al. [111] have purified various potential peroxidase from roots and hairy root cultures of turnip (Brassica napus). They develop a diagnostic test kit for determination of uric acid. This assay was based on the following reaction:

Uric acid $+\mathrm{O}_{2}+2 \mathrm{H}_{2} \mathrm{O} \longrightarrow$ Uricaseallantoin $+\mathrm{H}_{2} \mathrm{O}_{2}+\mathrm{CO}_{2}$ $\mathrm{H}_{2} \mathrm{O}_{2}+4$-aminophenazone + phenol $\rightarrow$ peroxidase $p$

-(benzoquinone)monoamine-phenazone

$\mathrm{MnP}$ produced by the basidiomycetes Bjerkandera adusta was used in acrylamide polymerization [112]. Styrene (industrial polymer), which is used for wrapping and transporting goods, unfortunately, when discharged into environment, causes serious pollution in for air, water and soil [113]. With proficient direct electron transfer (DET) properties with electrodes, $\mathrm{MnP}$ is also act as redox enzyme. It is used in development of biosensors based on DET, biofuel cell, and in synthesis of bioorganic [114]. $\mathrm{MnP}$ showed the mineralization of many environmental pollutants, and these are used in bioremediation process. 
Due to their potent ability to degrade various dyes, it degrades 1.1.1-tricholoro-2.2-bis-(4-chlorophenyl) ethane (DDT), 2.4.6-trinitrotoluene (TNT) and polycyclic aromatic hydrocarbons (PAHs) [115-119]. Peroxidase has also many practical analytical important applications in diagnostics kits formation, such as quantification of glucose, lactose, cholesterol, and uric acid.

Versatile peroxidases (EC 1.11.1.16) revealed a hybrid molecular building among LiPs and MnPs [120]. They are not specific for $\mathrm{Mn}$ (II) as in $3 \mathrm{MnPs}$, but also catalyze the oxidation of phenolic and non-phenolic substrate such as LiPs, in the absence of Mn [121]. In adverse to class I peroxidases, the class II peroxidases have $\mathrm{N}$-terminal signal peptide, four conserved disulfide bridges and calcium in their structure. Versatile peroxidase can oxidize various substrates under different environmental conditions. These are very interesting enzyme due to the fact that they contain unique active sites that are responsible for direct oxidation of many aromatic compounds, including lignin, in addition to the well-known Mn2 binding active site. Peroxidases including MnP predominantly used in ELISA test, in which it is used for labeling an antibody, are most common and consistent method detecting toxins, cancer risk in prostrate and bladder, and in many other analytes [81]. In addition, there are many other prospective applications of $\mathrm{MnP}$ such as the development of biosensors based on direct electron transfer (DET), effective biofuels cells and selective bioorganic synthesis [114]. Iwahara et al. [112] found that Bjerkandera adusta is used in polymerization of acrylamide. $\mathrm{MnP}$ isolated from $P$. chrysosporium can biodegrade styrene, which is an key polymer used as a raw materials for wrapping and shipping goods; it has polluted aquatic, terrestrial as well as atmospheric air [113].

Qin et al. [27] reported decolorization of many dyes such as Remazol Brilliant Violet 5R, indigo carmine, and methyl green as well as decolorization of textile wastewater by CD2-MnP enzyme. Recently, Xu et al. [35] found that $\mathrm{MnP}$ isolated from $\mathrm{G}$. lucidum 00679 decolorize/detoxify four dyes such as Drimaren Blue CLBR, Drimaren Red K-4B, Drimaren Yellow X-8GN and Disperse Navy Blue HGL. There are also many bacterial strains, which have been reported for the biodegradation of natural rubber by plate assay method [3].

Castillo et al. [122] observed that MnP extracted from white-rot fungus ( $P$. chrysosporium) has great potential to biodegrade bentazon in the presence of $\mathrm{Mn}$ (II) and Tween-80. In addition, during in vivo and in vitro experiments Castillo et al. [123] found that MnP isolated from $P$. chrysosporium have potential to degraded isoproturon (herbicide). Jiang et al. [76] reported that MnP activity was enhanced by the addition of hemoglobin $(\mathrm{Hb})$ in fermentation medium for mnp2 overexpressing in P. pastoris. In this experiment, it was speculating that the $\mathrm{Hb}$ could be assisted to supply biosynthesis of porphyrin in peroxidases. Pizzul et al. [124] reported that glyphosate (herbicide), which was biodegraded by MnP and laccase extracted from Nematoloma frowardii and T. versicolor in the presence of substrate ABTS [2.2'-azinobis (3-ethylbenzthiazoline-6-sulfonate)].

Many researchers reported that in wastewater many EDCs are present, which resist during the treatment process, and were removed efficiently by the diverse group of oxidative enzymes [83, 125, 126]. Baborová et al. [46] reported that $\mathrm{MnP}$ extracted and purified from I. lacteus have significant potential for the degradation of $\mathrm{PAHs}$ polychlorinated biphenyls and also several pentachlorophenol. In addition, recently the crude MnP enzyme extracted from I. lacteus F17 used for the degradation and detoxification of malachite green dye, which is reported as carcinogenic and mutagenic in nature [38]. In addition, various authors have reported that ligninolytic enzyme has great potential in many biotechnological applications, but unfortunately its lower catalytic efficiencies and its working stabilities limit their practical and versatile applications in many areas of the current industrial use [127-135].

\section{Conclusion and future prospects}

The microbial MnP remains the subject of demanding focused research for their potential applications in broad range of industrial and other biotechnological applications. This enzyme is present in almost all known bacteria and fungi. The bacterial MnP plays an imperative role in bioremediation of industrial wastes because it oxidizes number of xenobiotics compounds as well as nontoxic substrate and also used in industries like food industry, biosensor designing, paper and pulp, textile and distillery industry, diagnostic kits formation and in environmental protection. $\mathrm{MnP}$ is reported to catalyze the oxidation of several types of phenolic and non-phenolic compounds, with the aid of small molecules referred to as mediators. However, in recent years a new field of application for $\mathrm{MnP}$ is emerging in the cosmetic industry too, because these enzymes are used especially for the synthesis of flavonoids, pigments, cosmetic dyes as well as aromatic aldehydes and heterocyclic compounds, which are active ingredients in cosmetic products.

Acknowledgements The financial support received from "Science and Engineering Research Board" (SERB), Department of Science and Technology (DST), Government of India (GOI), New Delhi, as "Major Research Project" (Grant No.: EEQ/2017/000407), and Mr. Pankaj Chowdhary for Ph.D. work from University Grant Commission (UGC), Government of India (GOI), New Delhi, is duly acknowledged. 


\section{Compliance with ethical standards}

Conflict of interest The authors declare that they have no conflict of interest.

Ethical approval This article does not contain any studies with human participants or animals performed by any of the authors.

\section{References}

1. Qin $X$, Sun $X$, Huang $H$, Bai Y, Wang Y, Luo H, Yao B, Zhang X, Su X (2017) Oxidation of a non-phenolic lignin model compound by two Irpex lacteus manganese peroxidases: evidence for implication of carboxylate and radicals. Biotechnol Biofuels 10:103

2. Asgher M, Bashir F, lqbal HMN (2014) A comprehensive ligninolytic pre-treatment approach from lignocellulose green biotechnology to produce bio-ethanol. Chem Eng Res Des 92(8):1571-1578

3. Nayanashree G, Thippeswamy B (2015) Biodegradation of natural rubber by laccase and manganese peroxidase enzyme of bacillus subtilis. Environ Process 2(4):761-772

4. Bilal M, Asgher M, lqbal HMN, Hu H, Wang W, Zhang X (2017) Bio-catalytic performance and dye-based industrial pollutants degradation potential of agarose-immobilized $\mathrm{MnP}$ using a packed bed reactor system. Int J Biol Macromol 102:582-590

5. Cheng J, Yu SM, Zuo P (2006) Horseradish peroxidase immobilized on aluminium pillared interlayer clay for the catalytic oxidation of phenol water. Water Res 40:283-290

6. Iqbal and Asgher (2013) Characterization and decolorization applicability of xerogel matrix immobilized manganese peroxidase produced from Trametes versicolor IBL-04. Protein and Peptide Lett 20(5):591-600

7. Hammel KE, Cullen D (2008) Role of fungal peroxidases in biological ligninolysis. Curr Opin Plant Biol 11:349-355

8. Morgenstern I, Klopman S, Hibbett DS (2008) Molecular evolution and diversity of lignin degrading heme peroxidases in the Agaricomycetes. J Mol Evol 66:243-257

9. Ruiz-Dueñas FJ, Martínez AT (2009) Microbial degradation of lignin: how a bulky recalcitrant polymer is efficiently recycled in nature and how we can take advantage of this. Microbiol Biotechnol 2:164-177

10. Hofrichter M, Ullrich R, Pecyna MJ, Liers C, Lundell T (2010) New and classic families of secreted fungal heme peroxidases. Appl Microbiol Biotechnol 87:871-897

11. Floudas D et al (2012) The Paleozoic origin of enzymatic lignin decomposition reconstructed from 31 fungal genomes. Science 336:1715-1719

12. Paszcynski A, Huynh V-B, Crawford R (1986) Comparison of ligninase- 1 and peroxidase-M2 from the white-rot fungus Phanerochaete chrysosporium. Arch Biochem Biophys 244:750-765

13. Hatakka A (2001) Biodegradation of lignin. In: Hofrichter M, Steinbüchel A (eds) Biopolymers. Vol. 1-Lignin, humic substances and coal. Wiley, Weinheim, pp 129-180

14. Kersten P, Cullen D (2007) Extracellular oxidative systems of the lignin degrading Basidiomycete Phanerochaete chrysosporium. Fungal Genet Biol 44:77-87

15. Zhang Y, Zeng GM, Tang L, Huang DL, Jiang XY, Chen YN (2007) A hydroquinone biosensor using modified core-shell magnetic nanoparticles supported on carbon paste electrode. Biosens Bioelectron 22(9-10):2121-2126
16. Martinez D, Larrondo LF, Putnam N, Gelpke MDS, Huang K, Chapman J, Helfenbein KG, Ramaiya P, Detter JC, Larimer F (2004) Genome sequence of the lignocellulose degrading fungus Phanerochaete chrysosporium strain RP78. Nat Biotechnol 22(6):695-700

17. Martin H (2002) Review: lignin conversion by manganese peroxidase (MnP). Enzyme Microb Technol 30:454-466

18. Sundaramoorthy M, Kishi K, Gold MH, Poulos TL (1994) The crystal structure of manganese peroxidase from Phanerochaete chrysosporium at 2.06-A resolution. J Biol Chem 269:32759-32767

19. Asgher M, lqbal HMN (2013) Enhanced catalytic features of sol-gel immobilized $\mathrm{MnP}$ isolated from solid state culture of Pleurotus ostreatus IBL-02. Chin Chem Lett 24(4):344-346

20. Asgher M, Ahamad Z, lqbal HMN (2013) Alkali and enzymatic delignification of sugarcane bagasse to expose cellulose polymers for saccharification and bio-ethanol production. Ind Crops Prod 44:488-495

21. Nousiainen P, Kontro J, Manner H, Hatakka A, Sipila J (2014) Phenolic mediators enhance the manganese peroxidase catalyzed oxidation of recalcitrant lignin model compounds and synthetic lignin. Fungal Gen Biol 72:137-149

22. Barbosa ES, Perrone D, Vendramini ALA, Leite SGF (2008) Vanillin production by Phanerochaete chrysosporium grown on green coconut agro-industrial husk in solid state fermentation. Bioresources 3:1042-1050

23. Chowdhary P, Yadav A, Kaithwas G, Bharagava RN (2017) Distillery Wastewater: A Major Source of Environmental Pollution and Its Biological Treatment for Environmental Safety. In: Singh R, Kumar S (eds) Green technologies and environmental sustainability. Springer International, Switzerland, pp 409-435

24. Zhang H, Ji Zhang, Xiaoyu Zhang, Geng A (2018) Purification and characterization of a novel manganese peroxidase from white-rot fungus Cerrena unicolor BBP6 and its application in dye decolorization and denim bleaching. Process Biochem 66:222-229

25. Hakala TK, Hildén K, Maijala P, Olsson C, Hatakka A (2006) Differential regulation of manganese peroxidases and characterization of two variable MnP encoding genes in the whiterot fungus Physisporinus rivulosus. Appl Microbiol Biotechnol 73(4):839-849

26. Urek RO, Pazarlioglu NK (2007) Enhanced production of manganese peroxidase by Phanerochaete chrysosporium. Braz Arch Biol Technol 50(6):913-920

27. Qin X, Zhang J, Zhang X, Yang Y (2015) Induction, purification and characterization of a novel manganese peroxidase from Irpex lacteus CD2 and its application in the decolorization of different types of dye. PLoS ONE 9:113-282

28. Shamseldin A, Abdelkhalek Ahmed A (2015) Isolation and identification of newly effective bacterial strains exhibiting great ability of lignin and rice straw biodegradation. Int J Curr Microbiol Appl Sci 4(6):1039-1049

29. Huy ND, Tien NTT, Huyen LT, Quang HT, Tung TQ, Luong NN, Park SM (2017) Screening and production of manganese peroxidase from Fusarium sp. on residue materials. Mycobiology 45(1):52-56

30. Hildén K, Mäkelä MR, Steffen KT, Hofrichter $M$, Hatakka A, Archer DB, Lundell TK (2014) Biochemical and molecular characterization of an atypical manganese peroxidase of the litter-decomposing fungus Agrocybe praecox. Fungal Genet Biol 72:131-136

31. Pease EA, Tien M (1992) Heterogeneity and regulation of manganese peroxidases from Phanerochaete chrysosporium. J Bacteriol 174:3532-3540 
32. Gettemy JM, Ma B, Alic M, Gold MH (1998) Reverse transcription-PCR analysis of the regulation of the manganese peroxidase gene family. Appl Environ Microbiol 64:569-574

33. Shi Y, Chai L, Tang C, Yang Z, Zhang H, Chen R, Chen Y, Zheng $Y$ (2013) Characterization and genomic analysis of kraft lignin biodegradation by betaproteobacteriaum Cupridvidus basilensis B-8. Biotechnol Biofuels 6:1

34. Salvachua D, Martinez AT, Tien M, Lopez-Lucendo MF, Garcia F, de Los Rios V, Martinez MJ, Prieto A (2013) Differential proteomic analysis of the secretome of Irpex lacteus and other white-rot fungi during wheat straw pretreatment. Biotechnol Biofuels 6:115

35. Xu H, Guo M-Y, Gao Y-H, Bai X-H, Zhou X-W (2017) Expression and characteristics of manganese peroxidase from Ganoderma lucidum in Pichia pastoris and its application in the degradation of four dyes and phenol. BMC Biotechnol. https ://doi.org/10.1186/s12896-017-0338-5

36. Zhang H, Zhang S, He F, Qin X, Zhang X, Yang Y (2016) Characterization of a manganese peroxidase from white-rot fungus Trametes sp. 48424 with strong ability of degrading different types of dyes and polycyclic aromatic hydrocarbons. J Hazard Mater 320:265-277

37. Bilal M, Asgher M (2016) Enhanced catalytic potentiality of Ganoderma lucidum IBL-05 manganese peroxidase immobilized on sol-gel matrix. J Mol Catal B Enzym 128:82-93

38. Yang X, Zheng J, Lu Y, Jia R (2016) Degradation and detoxification of the triphenylmethane dye malachite green catalyzed by crude manganese peroxidase from Irpex lacteus. Environ Sci Pollut Res 23:9585-9597

39. Silva MLC, Souza VB, Santos VS, Kamida HM, Vasconcellos-Neto JRT, Góes-Neto A, Koblitz MGB (2014) Production of manganese peroxidase by Trametes villosa on unexpensive substrate and its application in the removal of lignin from agricultural wastes. Adv Biosci Biotechnol 5:1067-1077

40. Koyani RD, Sanghvi GV, Sharma RK, Rajput KS (2013) Contribution of lignin degrading enzymes in decolourisation and degradation of reactive textile dyes. Int Biodeterior Biodegradation 77:1-9

41. Chang AJ, Fan J, Wen X (2012) Screening of fungi capable of highly selective degradation of lignin in rice straw. Int Biodeterior Biodegradation 72:26-30

42. Singh D, Zeng J, Chen Z (2011) Increasing manganese peroxidase productivity of Phanerochaete chrysosporium by optimizing carbon sources and supplementing small molecule. Lett Appl Microbiol 53:120-123

43. Asgher M, Ahmad N, lqbal HMN (2011) Hyper productivity of extracellular enzymes from indigenous white rot fungi $(P$. chrysosporium IBL-03) by utilizing agro wastes. Bio Resources 6:4454-4467

44. Irshad M, Asgher M (2011) Production and optimization of ligninolytic enzymes by white rot fungus Schizophyllum commune IBL-06 in solid state medium banana stalks. Afr J Biotech 10:18234-18242

45. Tanaka H, Koike K, Itakura S, Enoki A (2009) Degradation of wood and enzyme production by Ceriporiopsis subvermispora. Enzyme Microb Technol 45(5):384-390

46. Baborova P, Moder M, Baldrian P, Cajthamlova K, Cajthaml T (2006) Purification of a new manganese peroxidase of the white-rot fungus Irpex lacteus and degradation of polycyclic aromatic hydrocarbons by the enzyme. Res Microbiol 157:248-253

47. Vares T, Kalsi M, Hatakka A (1995) Lignin peroxidases, manganese peroxidases and other ligninolytic enzymes produced by Phlebia radiata during solid state fermentation of wheat straw. Appl Environ Microbiol 61:3515-3520
48. Chandra R, Bharagava RN, Rai V, Singh SK (2009) Characterization of sucrose glutamic acid Millard products (SGMPs) degrading bacteria and their metabolites. Bioresour Technol 100:6665-6668

49. Mino Y, Wariishi H, Blackburn NJ, Loehr TM, Gold MH (1988) Spectral Characterization of manganese peroxidase, an extracellular heme enzyme from the lignin-degrading basidiomycete, Phanerochaete chrysosporium. J Biol Chem 263:7029-7036

50. Sundaramoorthy M, Kishi K, Gold MH, Poulos TL (1997) Crystal structure of substrate binding site mutants of manganese peroxidase. J Biol Chem 272:17574-17580

51. Sundaramoorthy M, Youngs HL, Gold MH, Poulos TL (2005) High-resolution crystal structure of manganese peroxidase: substrate and inhibitor complexes. Biochemistry 44:6463-6470

52. Watanabe $Y$, Nakajima $\mathrm{H}$ (2016) Creation of a thermally tolerant peroxidase. In: Pecoraro VL (ed) Methods in enzymology, vol 580. Academic Press, Cambridge, pp 455-470

53. Kishi K, Wariishi H, Marquez L, Dunford HB, Gold MH (1994) Mechanism of manganese peroxidase compound II reduction. Effect of organic acid chelators and $\mathrm{pH}$. Biochemistry 33:8694-8701

54. Martinez-Ingio MJ, Kurek B (1997) Oxidative degradation of alkali wheat straw lignin by fungal lignin peroxidase, manganese peroxidase and laccase: a comparative study. Holzforschung 51:543-548

55. Elisashvili V, Kachlishvili E (2009) Physiological regulation of laccase and manganese peroxidase production by white-rot Basidiomycetes. J Biotechnol 144:37-42

56. Mikiashvili N, Elisashvili V, Wasser S, Nevo E (2005) Carbon and nitrogen sources influence the ligninolytic enzyme activity of Trametes versicolor. Biotechnol Lett 27:955-959

57. Wang P, Hu X, Cook S, Begonia M, Lee KS, Hwang HM (2008) Effect of culture conditions on the production of ligninolytic enzymes by white rot fungi Phanerochaete chrysosporium (ATCC 20696) and separation of its lignin peroxidase. World J Microbiol Biotechnol 24:2205-2212

58. Vrsanska M, Buresova A, Damborsky P, Adam V (2015) Influence of different inducers on ligninolytic enzyme activities. J Metastab Nanocryst Mater 3:64-70

59. Reddy CA, D'Souza TM (1994) Physiology and molecular biology of the lignin peroxidases of Phanerochaete chrysosporium. FEMS Microbiol Rev 13:137-152

60. Saparrat MCN, Guillen F, Arambarri AM, Martinez AT, Martinez MJ (2002) Induction, isolation, and characterization of two laccases from the white rot basidiomycete Coriolopsis rigida. Appl Environ Microbiol 68:1534-1540

61. Kapich AN, Prior BA, Botha A, Galkin S, Lundell T, Hatakka A (2004) Effect of lignocellulose-containing substrate on production of ligninolytic peroxidases in submerged cultures of Phanerochaete chrysosporium ME-446. Enzym Microb Technol 34:187-195

62. Songulashvili G, Elisashvili V, Wasser SP, Nevo E, Hadar Y (2007) Basidiomycetes laccase and manganese peroxidase activity in submerged fermentation of food industry waste. Enzym Microb Technol 41(1-2):57-61

63. Novotný C, Svobodova K, Erbanova P, Cajthaml T, Kasinath A, Lang E, Sasek V (2004) Ligninolytic fungi in bioremediation: extracellular enzyme production and degradation rate. Soil Biol Biochem 36:1545-1551

64. Gassara F, Brar SK, Tyagi RD, Verma M, Surampalli RY (2010) Screening of agro-industrial wastes to produce ligninolytic enzymes by Phanerochaete chrysosporium. Biochem Eng J 49:388-394

65. Usha KY, Praveen K, Reddy BR (2014) Enhanced production of ligninolytic enzymes by a mushroom Stereum ostrea. Biotechnol Res Int. https://doi.org/10.1155/2014/815495 
66. Gadd GM (1993) Interactions of fungi with toxic metals. New Phytol 124:25-60

67. Shimada M, Akamtsu Y, Tokimatsu T, Mii K, Hattori T (1997) Possible biochemical roles of oxalic acid as a low molecular weight compound involved in brown-rot and white-rot decays. J Biotechnol 53:101-113

68. Asgher M, lqbal HMN (2011) Characterization of a novel manganese peroxidase purified from solid state culture of Trametes versicolor IBL-04. Bio Resources 6:4317-4330

69. Fujii K, Uemura M, Hayakawa C, Funakawa S, Kosaki T (2013) Environmental control of lignin peroxidase, manganese peroxidase, and laccase activities in forest floor layers in humid Asia. Soil Biol Biochem 57:109-115

70. Couto SR, Rosales E, Gundin M, Sanroman MA (2004) Exploitation of wastes from the brewing industry for laccase production by two Trametes species. J Food Eng 64:423-428

71. Stajić M, Persky L, Friesem D, Hadar Y, Wasser SP, Nevo E, Vokojević J (2006) Effect of different carbon and nitrogen sources on laccase and peroxidases production by selected Pleurotus species. Enzym Microb Technol 38(1):65-73

72. Pedri ZC, Lozano LMS, Hermann KL, Helm CV, Peralta RM, Tavares LBB (2015) Influence of nitrogen sources on the enzymatic activity and grown by Lentinula edodes in biomass Eucalyptus benthamii. Braz J Biol 75:940-947

73. Elisashvili V, Kachlishvili E, Penninckx M (2008) Effect of growth substrate, method of fermentation, and nitrogen source on lignocellulose-degrading enzymes production by white-rot basidiomycetes. J Ind Microbiol Biotechnol 35:1531-1538

74. Prasher IB, Chauhan R (2015) Effect of carbon and nitrogen sources on the growth, reproduction and ligninolytic enzymes activity of dictyoarthrinium synnematicum Somrith. Adv Zool Bot 3(2):24-30

75. Patrick F, Mtui G, Mshandete AM, Kivaisi A (2011) Optimization of laccase and managnese peroxidase production in submerged culture of Pleurotus sajor-caju. Afr J Biotechnol 10(50):10166-10177

76. Jiang F, Kongsaeree $\mathrm{P}$, Schilke $\mathrm{K}$ et al (2007) Effects of $\mathrm{pH}$ and temperature on recombinant manganese peroxidase production and stability. Appl Biochem Biotechnol 146:15-27

77. Asina F, Brzonova I, Kozliak E, Kubátová A, Ji Y (2017) Microbial treatment of industrial lignin: successes, problems and challenges. Renew Sustain Energy Rev 77:1179-1205

78. Casciello C, Tonin F, Berini F, Fasoli E, Marinelli F, Pollegioni L, Rosini E (2017) A valuable peroxidase activity from the novel species Nonomuraea gerenzanens is growing on alkali lignin. Biotechnol Rep 13:49-57

79. Kong W, Chen H, Lyu S, Ma F, Yu H, Zhang X (2016) Characterization of a novel manganese peroxidase from white-rot fungus Echinodontium taxodii 2538, and its use for the degradation of lignin-related compounds. Process Biochem 51:1776-1783

80. Plácido J, Capareda S (2015) Ligninolytic enzymes: a biotechnological alternative for bioethanol production. Bioresour Bioprocess 2(1):1-12

81. Hamid M, Khalil-ur-Rehman (2009) Potential applications of peroxidases. Food Chem 115:1177-1186

82. Chandra R, Chowdhary P (2015) Properties of bacterial laccases and their application in bioremediation of industrial wastes. Environ Sci Processes Impacts 17:326-342

83. Chowdhary P, Raj A, Bharagava RN (2018) Environmental pollution and health hazards from distillery wastewater and treatment approaches to combat the environmental. Chemosphere 194:229-246

84. Kim GY, Lee KB, Cho SH, Shim J, Moon SH (2005) Electroenzymatic degradation of azo dye using an immobilized peroxidase enzyme. J Hazard Mater 126:183-188
85. Mohan SV, Prasad KK, Rao NC, Sarma PN (2005) Acid azo dye degradation by free and immobilized horseradish peroxidase (HRP) catalyzed process. Chemosphere 58:1097-1105

86. Shin KS (2004) The role of enzymes produced by white-rot fungus Irpex lacteus in the decolorization of the textile industry effluent. J Microbiol 42:37-41

87. Champagne PP, Ramsay JA (2005) Contribution of manganese peroxidase and laccase to dye decolouration by Trametes versicolor. Appl Microbiol Biotechnol 69:276-285

88. Reddy GVB, Sridhar M, Gold MH (2003) Cleavage of nonphenolic $\beta-1$ diarylpropane lignin model dimers by manganese peroxidase from Phanerochaete chrysosporium. Eur J Biochem 270:284-292

89. Iqbal HMN, Kyazze G, Keshavarz T (2013) Advances in the valorization of lignocellulosic materials by biotechnology: an overview. Bio Resources 8(2):3157-3176

90. Zainith S, Chowdhary P, Yadav A, Kaithwas G, Bharagava RN (2018) Recent Advances in Physico-chemical and Biological Techniques for the Management of Pulp and Paper Mill Waste. In: Bharagava RN, Chowdhary P (eds) Emerging and ecofriendly approaches for waste management. Springer International, Singapore, pp 271-297

91. Arana A, Tellez A, Gonzalez T, Gonzalez A (2002) Aspectos generales de la biodegradacion de la Madera: applicaciones industriales de las laccasas. Biotechnology 7:40-55

92. Li K (2003) The role of enzymes and mediators in white-rot fungal degradation of lignocellulose. In: Goodell B, Nicholus DD, Schaltz TP (eds) Wood determination and preservation. ACS symposium series, vol 845. ACS, Washington, pp 196-209

93. Jimenez L, Martinez C, Perez I, Lopez F (1997) Biobleaching procedures for pulp from agricultural residues using Phanerochaete chrysosporium and enzymes. Process Biochem 32:297-304

94. Katagiri N, Tsutsumi Y, Nishida T (1995) Correlation of brightening with cumulative enzyme activity related to lignin biodegradation during biobleaching of Kraft pulp by white-rot fungi in the solid-state fermentation system. Appl Environ Microbiol 61:617-622

95. Hatakka A, Lundell T, Hofrichter M, Maijala P (2003) Manganese peroxidase and its role in the degradation of wood lignin. In: Mansfield SD, Saddler JN (eds) Applications of enzymes to ligninocellulosics, ACS symposium series, vol 855. ACS, Washington, pp 230-243

96. Feijoo G, Moreira MT, Lema JM (2002) Effect of $\mathrm{Co}^{+2}$ in delignification of kraft paste by Phanerochaete chrysosporium. Afinidad 59:586-591

97. Poonpairoj P, Peerapatsakul C, Chitadron L (2001) Trend in using fungal enzymes, lignin-and pectin-degrading enzymes, and improvement of the paper mulberry pulping process. Biotechnol Sustain Util Biol Res 15:56-65

98. Moreira MT, Feijoo G, Canaval J, Lema JM (2003) Semipilot-scale bleaching of kraft pulp with manganese peroxide. Wood Sci Technol 37:117-1234

99. Raj A, Kumar S, Haq I, Singh SK (2014) Bioremediation and toxicity reduction in pulp and paper mill effluent by newly isolated ligninolytic Paenibacillus sp. Ecol Eng 71:355-362

100. Bilal M, Asgher M, lqbal HMN, Hu HB, Zhang XH (2016) Gelatinimmobilized manganese peroxidase with novel catalytic characteristics and its industrial exploitation for fruit juice clarification purposes. Catal Lett 146(11):2221-2228

101. Bilal M, Asgher M, lqbal HMN, Hu H, Zhang X (2017) Delignification and fruit juice clarification properties of alginate-chitosan-immobilized ligninolytic cocktail. LWT-Food Sci Technol 80:348-354 
102. Zorn H, Langhoff S, Scheibner M, Nimtz M, Berger RG (2003) A peroxidase from Lepistairina cleaves $\mathrm{b}, \mathrm{b}$-carotene to flavor compounds. Biol Chem 384:1049-1056

103. Moreno AD, Ibarra D, Fernández JL, Ballesteros M (2012) Different laccase detoxification strategies for ethanol production from lignocellulosic biomass by the thermotolerant yeast Kluyveromyces marxianus CECT 10875. Bioresour Technol 106:101-109

104. Mussatto SI, Dragone G, Roberto IC (2007) Ferulic and p-coumaric acids extraction by alkaline hydrolysis of brewer's spent grain. Ind Crop Prod 25:231-237

105. Chandel AK, Kapoor RK, Singh A, Kuhad RC (2007) Detoxification of sugarcane bagasse hydrolysate improves ethanol production by Candida shehatae NCIM 3501. Bioresour Technol 98:1947-1950

106. Ferreira P, Medina M, Guillén F, Martinez M, Van Berkel W, Martinez A (2005) Spectral and catalytic properties of aryl-alcohol oxidase, a fungal flavoenzyme acting on polyunsaturated alcohols. Biochem J 389:731-738

107. Pant $D$, Adholeya A (2007) Enhanced production of ligninolytic enzymes and decolorization of molasses distillery wastewater by fungi under state fermentation. Biodegradation 18:647-659

108. Bilal M, Nawaz MZ, Iqbal HMN, Hou J, Mahboob S, Al-Ghanim $\mathrm{KA}$, Cheng $\mathrm{H}$ (2018) Engineering ligninolytic consortium for bioconversion of lignocelluloses to ethanol and chemicals. Protein Pept Lett 25(2):108-119

109. Asgher M, Aslam B, lqbal HMN (2013) Novel catalytic and effluent decolorization functionalities of sol-gel immobilized Pleurotus ostreatus IBL-02 manganese peroxidase produced from bio-processing of wheat straw. Chin J Catal 34(9):1756-1761

110. Bilal M, Asgher M, Iqbal HMN, Ramzan M (2017) Enhanced bio-ethanol production from old newspapers waste through alkali and enzymatic delignification. Waste Biomass Valoriz 8(7):2271-2281

111. Agostini E, Hernandez-Ruiz J, Arnao MB, Milrand SR, Tigier HA, Acosta M (2002) A peroxidase isoenzyme secreted by turnip (Brassica napus) hairy-root culture inactivation by hydrogen peroxide and application in diagnostic kits. Biotechnol Appl Biochem 35:17

112. Iwahara K, Hirata M, Honda Y, Watanabe T, Kuwahara M (2000) Free-radical polymerization of acrylamide by manganese peroxidase produced by the white-rot basidiomycetes Bjerkandra adusta. Biotech Lett 22:1351-1361

113. Lee JW, Lee SM, Hong EJ, Jeung EB, Kang HY, Kim MK, Choi IG (2006) Estrogenic reduction of styrene monomer degraded by Phanerochaete chrysosporium KFRI20742. J Microbiol 44:177-184

114. Ferapontova EE, Shleev S, Ruzgas T, Stoica L, Christenson A, Tkac J, Yaropolov Al, Gorton L (2005) Direct electrochemistry of proteins and enzymes. Electrochemistry of nucleic acids and proteins. Elsevier, In Perspectives in Bioanalysis

115. Abraham W-R, Nogales B, Golyshin PN, Pieper DH, Timmis KN (2002) Polychlorinated biphenyl-degrading microbial communities in soils and sediments. Curr Opin Microbiol 5:246-253

116. Ohtsubo Y, Kudo T, Tsuda M, Nagata Y (2004) Strategies for bioremediation of polychlorinated biphenyls. Appl Microbiol Biotechnol 65:250-258

117. Robles-Hernandez L, Gonzàlez-Franco AC, Crawford DL, Chun WWC (2008) Review of environmental organo-pollutant degradation by white-rot basidiomycetes mushrooms. Tecnociencia Chihuahua 2(1):32-39

118. Gomes E, Aguiar AP, Carvalho CC, Bonfá MRB, da Silva R, Boscolo M (2009) Ligninases production by Basidiomycetes strains on lignocellulosic agricultural residues and their application in the decolorization of synthetic dyes. Braz J Microbiol 40:31-39
119. Wen X, Jia Y, Li J (2009) Degradation of tetracycline and oxytetracycline by crude lignin peroxidase prepared from Phanerochaete chrysosporium-a white rot fungus. Chemosphere 75(8):1003-1007

120. Perez-Boada M, Ruiz-Dueñas FJ, Pogni R, Basosi R, Choinowski T et al (2005) Versatile peroxidase oxidation of high redox potential aromatic compounds: site-directed mutagenesis, spectroscopic and crystallographic investigation of three long-range electron transfer pathways. J Mol Biol 354:385-402

121. Martinez M, Ruiz-Duenas FJ, Guillen F, Martinez AT (1996) Purification and catalytic properties of two manganese peroxidase isoenzymes from Pleurotus eryngii. Eur J Biochem 237:424-432

122. Castillo M, Ander P, Stenström J, Torstensson L (2000) Degradation of the herbicide bentazon as related to enzyme production by Phanerochaete chrysosporium in two solid substrate fermentation system. World J Microbial Biotechnol 16:289-295

123. Castillo MD, von Wiren-Lehr S, Scheunert I, Torstensson L (2001) Degradation of isoproturon by the white rot fungus Phanerochaete chrysosporium. Biol Fert Soils 33(6):521-528

124. Pizzul L, Castillo MDP, Stenström J (2009) Degradation of glyphosate and other pesticides by ligninolytic enzymes. Biodegradation 20(6):751-759

125. Zheng W, Colosi LM (2011) Peroxidase-mediated removal of endocrine disrupting compound mixtures from water. Chemosphere 85(4):553-557

126. Bilal $M$, Asgher $M$, lqbal $H M, H u H$, Zhang X (2017) Bio-based degradation of emerging endocrine-disrupting and dye-based pollutants using cross-linked enzyme aggregates. Environ Sci Pollut Res 24(8):7035-7041

127. Asgher M, Irshad M, Iqbal HMN (2013) Purification and characterization of novel manganese peroxidase from Schizophyllum commune IBL-06. Int J Agric Biol 15:749-754

128. Asgher M, Yasmeen Q, lqbal HMN (2014) Development of novel enzymatic bioremediation process for textile industry effluents through response surface methodology. Ecol Eng 63:1-11

129. Asgher M, Shahid M, Kamal S, Iqbal HMN (2014) Recent trends and valorization of immobilization strategies and ligninolytic enzymes by industrial biotechnology. J Mol Cata B: Enzym 101:56-66

130. Asgher M, Shah HA, Iqbal HMN (2016) Statistical correlation between ligninolytic enzymes secretion and Remazol Brilliant Yellow-3GL dye degradation potential of Trametes versicolor IBL-04. Water Environ Res 88(4):338-345

131. Asgher M, Wahab A, Bilal M, Iqbal HMN (2017) Delignification of lignocellulose biomasses by alginate-chitosan immobilized laccase produced from Trametes versicolor IBL-04. Waste Biomass Valori 9(11):2071-2079

132. Bilal M, Asgher M, Parra-Saldivar R, Hu H, Wang W, Zhang X, Iqbal HMN (2017) Immobilized ligninolytic enzymes: an innovative and environmental responsive technology to tackle dye-based industrial pollutants-a review. Sci Total Environ 576:646-659

133. Bilal M, Rasheed T, Zhao Y, Iqbal HMN, Cui J (2018) "Smart" chemistry and its application in peroxidase immobilization using different support materials. Int J Biol Macromol 119:278-290

134. Bilal M, lqbal HM, Hu H, Wang W, Zhang X (2018) Metabolic engineering and enzyme-mediated processing: a biotechnological venture towards biofuel production-a review. Renew Sust Energy Rev 82:436-447

135. Bilal M, Rasheed T, Iqbal HMN, Yan Y (2018) Peroxidases-assisted removal of environmentally-related hazardous pollutants with reference to the reaction mechanisms of industrial dyes. Sci Total Environ 644:1-13 